\title{
ОЦЕНКА СТИМУЛИРУЮЩЕГО ДЕЙСТВИЯ РЕГЛАЛГА В СОЧЕТАНИИ С МИКРОЭЛЕМЕНТАМИ У РАЗНЫХ СОРТОВ СЛИВЫ
}

\author{
Титова Нина, Попович Ана \\ Институт генетики, физиологии и защиты растений, Кишинэу, Республика Молдова \\ e-mail: nina.titova@igfpp.md
}

\begin{abstract}
The article presents the results of a study the influence of the bioregulator Reglalg, isolated from the alga Spirogira biomass, in combination with microelements $\mathrm{B}, \mathrm{Zn}, \mathrm{Mn}$, Mo on the plum plants physiological characteristics. A significant stimulating effect of such treatment on the mass and surface of leaves, the net productivity of photosynthesis and oxidative enzymes activity in the leaves of late local and introduced plum varieties was revealed.
\end{abstract}

Key words: plum trees, bioregulator Reglalg, microelements B, Zn, Mn, Mo; leaves growth, net photosynthesis productivity, oxidative enzymes activity.

\section{Введение}

Регулирование роста и развития растительного организма с целью реализации его потенциальных возможностей являются приоритетными направлениями в физиологии плодовых растений. Одним из важнейших факторов такой регуляции является использование биологически активных соединений, что может обеспечить оптимальную реализацию взаимоотношений роста, фотосинтеза, и получение максимальной продуктивности растений [1]. При этом очень важным является поиск биорегуляторов натурального происхождения и их применения с другими соединениями. К таким природным регуляторам относится биопрепарат Реглалг, полученный из биомассы водоросли Spirogira. Ранее было исследовано влияние ряда микроэлементов на фотосинтез, продуктивность и устойчивость к засухе плодовых растений [2,3]. . Имеется информация о стимулирующем влиянии биологически активных соединений на фотосинтез, метаболизм и урожайность у растений яблони, абрикоса, персика и груши [4]. Изучение совместного влияния Реглалга с микроэлементами на развитие растительного организма и формирование генотипа с хорошим фотосинтетическим обеспечением процессов роста и морфогенеза, а также взаимоотношений в системе донор-акцептор на разных уровнях, представляло важной задачей в теоретическом и практическом аспекте. Научные данные в таком направлении с растениями сливы практически отсутствуют.

Цель работы - изучение особенностей процессов роста и метаболизма у разных сортов сливы при действии препарата Реглалг в комбинации с микроэлементами B, Zn, Mn, Mo.

\section{Материалы и методы}

В плодовом саду Института Плодоводства и Пищевых Технологий изучали 4 поздних сорта сливы: местные сорта Удлиненная и Супепрезидент и интродуцированные сорта Стэнлей американской селекции и Президент английской селекции. После цветения и в период интенсивного роста растения сливы были обработаны по схеме: контроль - растения, опрыснутые водой; опыт - растения, опрыснутые смесью $0,05 \%$ водного раствора биопрепарата Реглалг с 0,01\% водным раствором смеси солей микроэлементов (борная кислота, цинк сернокислый, марганец сернокислый, молибден сернокислый).

В течение вегетации проведено изучение листовой поверхности, массы, удельной поверхностной плотности и чистой продуктивности фотосинтеза листьев [5]; динамики накопления фотосинтетических пигментов - хлорофиллов и каротиноидов [6]; активности окислительновосстановительных ферментов пероксидазы и полифенолоксидазы в листьях сливы [7, 8]. Статистическая обработка данных в программе Excel. 


\section{Результаты и обсуждение}

Исследования показали высокую отзывчивость растений сливы всех изучаемых сортов на обработку Реглалгом в комплексе с микроэлементами $\mathrm{B}, \mathrm{Zn}, \mathrm{Mn}, \mathrm{Mo}$ и стимулирующее влияние такой обработки на важнейшие факторы в продуктивности растений: ростовые и метаболические характеристики и фотосинтетическую деятельность деревьев. В период интенсивного роста побегов и развертывания листовой поверхности ответная реакция проявилась наиболее четко. Динамика накопления биомассы у всех растений близка (рис.1). Средние значения биомассы листа в контроле и опыте за всю

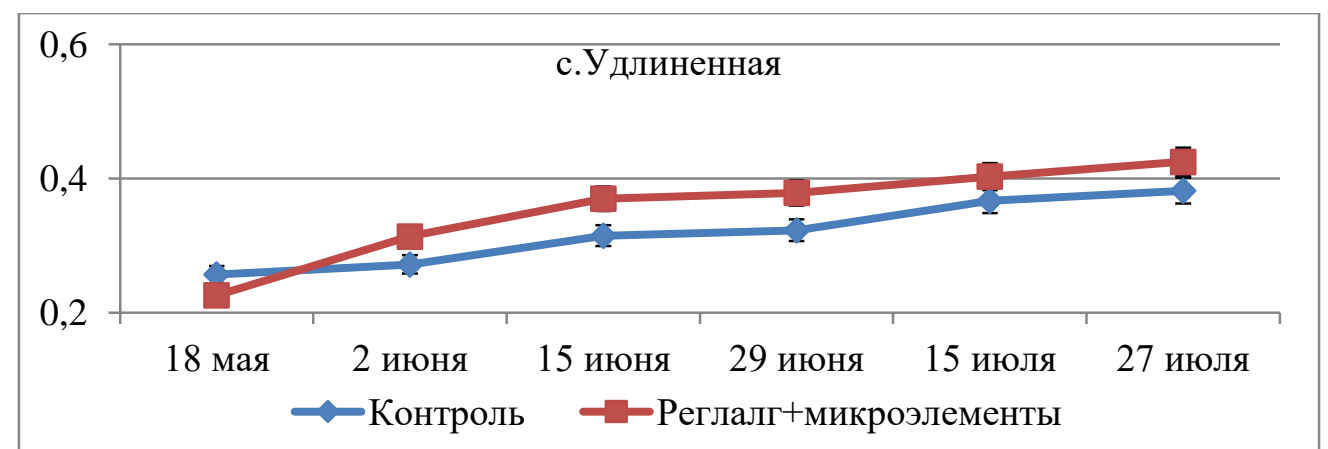

Рис.1. Динамика накопления сухой массы листа растений сливы сорта Удлиненная при обработке Реглалгом в комбинации с микроэлементами B, Zn, Mn, Mo ,(г).

вегетацию у местных сортов Удлиненная и Суперпрезидент составили соответственно 0,319 и 0,352 г и 0,310 и 0,363 г. У интродуцированных сортов Стэнлей и Президент эти величины равнялись соответственно 0,277 и 0,278 г и 0,238 и 0,243 г., что значительно ниже различий между вариантами у сортов местной селекции.

Известно, что реализация генетической программы развития растительного организма требует хорошего фотосинтетического обеспечения процессов роста и морфогенеза и оптимальных взаимоотношений между аттрагирующей мощностью растения и необходимой для её обеспечения площадью листьев [9]. Такая тесная взаимосвязь наблюдается при обработке растений сливы Реглалгом с комплексом микроэлементов (рис.2).

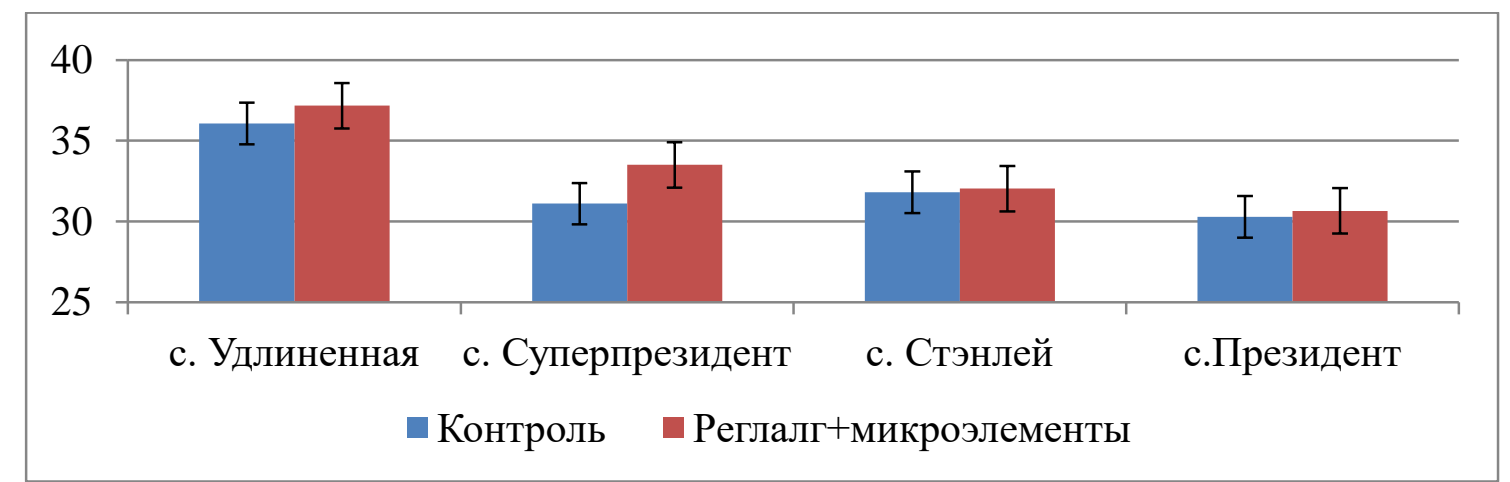

Рис.2. Изменение средней за вегетацию площади листа разных сортов сливы под влиянием обработки Реглалгом со смесью микроэлементов $\left(\mathrm{cm}^{2}\right)$.

Выявлено значительное увеличение удельной поверхностной плотности листа (УППЛ), отражающий по литературным данным [10] мезоструктурную организацию листа. Изменения УППЛ под влиянием обработки Реглалгом с микроэлементами у интродуцированных сортов не выявлены, тогда как у сортов местной селекции Удлиненная и Суперпрезидент различия между контролем и опытом составили соответственно 8,70 и 9,20 и 8,99 и 10,29 мгсм-2.

Определения накопления биомассы листьев и листовой поверхности в течение вегетации позволили рассчитать чистую продуктивность фотосинтеза (ЧПФ) листьев исследуемых сортов сливы при обработке Реглалгом совместно с микроэлементами. Средние значения ЧПФ (мг сухой 
биомассы листа·дм ${ }^{-2} \cdot$ час $^{-1}$ ) за вегетацию у опытных вариантов сортов Удлиненная, Суперпрезидент, Стэнлей и Президент составили соответственно к контролю 142, 137, 125 и 122 \%.

Результаты анализа накопления ассимиляционных пигментов, показателем быстрого реагирования на внешние воздействия. также показали стимулирующее действие Реглалга с микроэлементами на синтез хлорофиллов $a$ и $\sigma$ и каротиноидов. Через две недели и далее в течение вегетации обнаружено преимущество опытного варианта над контролем у всех сортов, но более выражено у сортов местной селекции Удлиненная и Суперпрезидент. По средней величине суммы хлорофиллов за вегетацию превышение обработанных растений над контролем у сорта Удлиненная составило около 4\%, у сорта Суперпрезидент - 8,3\% и у импортных сортов Стэнлей и Президент соответственно 2 и 3\%. По сумме каротиноидов значительных различий между контролем и опытом не обнаружено. Исключение составляет сорт Суперпрезидент, где в листьях обработанных растений количество желтых пигментов выше контроля на 3,8\%.

В наиболее засушливый период вегетации в июне различия между вариантами были более существенны. Этому способствовала более высокая влажность листьев у растений сливы, обработанных Реглалгом с микроэлементами. Эти отличия от контроля составляли 2-3 \%, что являлось особенно важным при засухе, так как по данным П.А Генкель [11] снижение содержания воды в листьях даже на 0,9 \% могло изменять баланс ауксинов и ингибиторов в сторону ингибиторов.

Сохранение оптимальной оводненности листьев сливы в течение вегетации (61-64\%) способствует высокой активности ключевых ферментов метаболизма пероксидазы и полифенолоксидазы у всех растений. Динамика этих энзимов идентична у разных сортов и вариантов. В конце июня - начале июля, в период роста плодов, активность исследуемых ферментов находится на высоком уровне. В засушливый период в эти сроки четко проявляется взаимозаменяемость пероксидазы и полифенолоксидазы, что позволило выявить их вклад в метаболизм растений в самые важнейшие фазы онтогенеза.

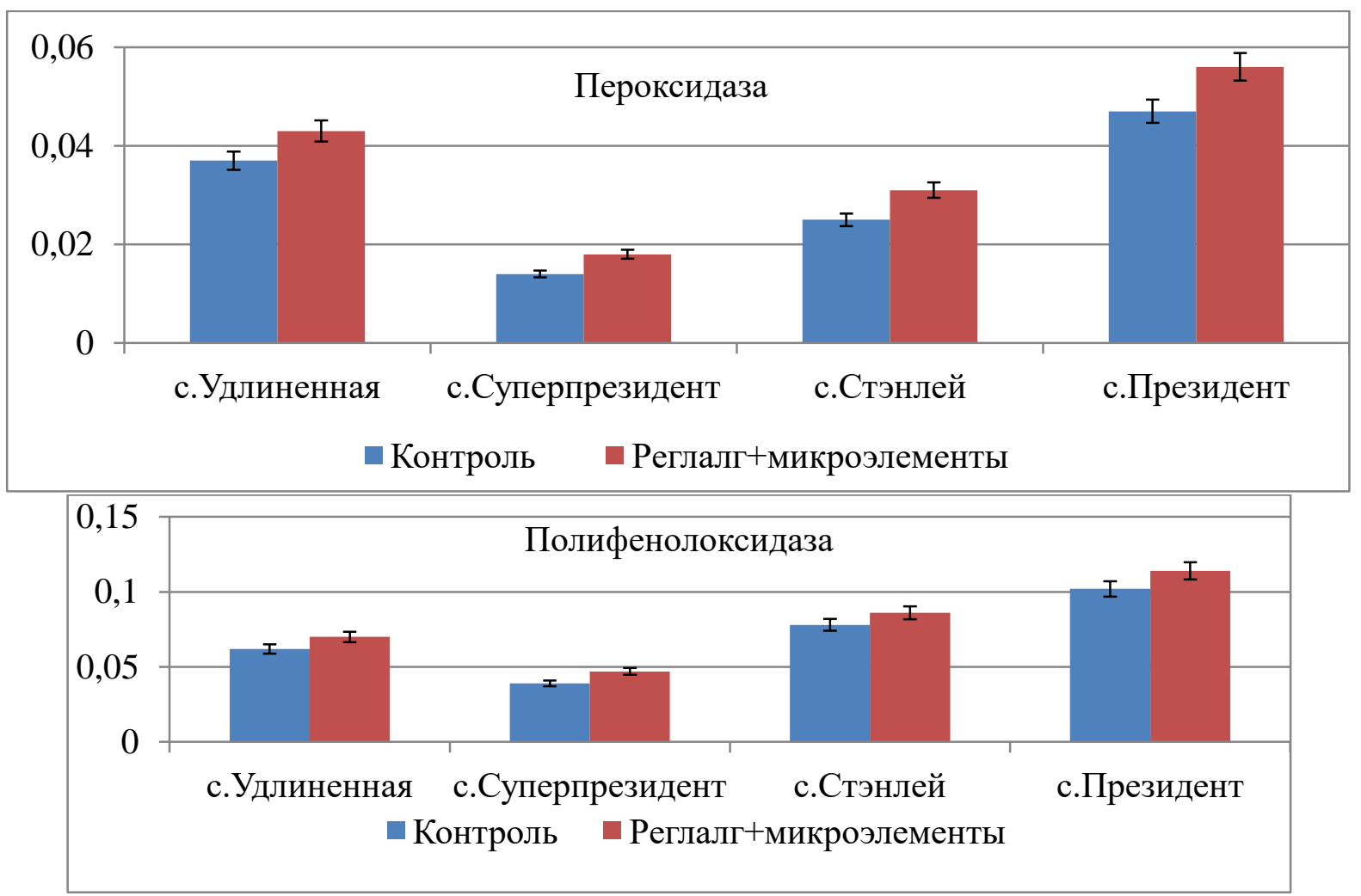

Рис.3. Средние значения активности окислительных ферментов за период вегетации в листьях разных сортов сливы (усл. ед.).

Сравнение средних значений активности этих ферментов за вегетацию показало особенности физиологических механизмов метаболизма в листьях местных и интродуцированных сортов сливы (рис.3). Сорта Удлиненная и Президент отличаются высокой активностью пероксидазы и 
полифенолоксидазы, тогда как сорта Стенлей и особенно Суперпрезидент занимают промежуточное положение. У интродуцированных сортов Стэнлей и Президент активность полифенолоксидазы в листьях значительно превышает активность у местных сортов.

\section{Выводы}

Выявлено, что натуральный биологически активный препарат Реглалг в сочетании с микроэлементами $\mathrm{B}, \mathrm{Zn}, \mathrm{Mn}$, Мо стимулирует формирование и функционирование фотосинтетического аппарата (масса и площадь листьев, чистая продуктивность фотосинтеза, активность ферментов пероксидаза и полифенолоксидаза в листьях, накопление фотосинтетических пигментов - хлорофиллов а и б, каротиноидов) у поздних местных сортов сливы Удлиненная и Суперпрезидент и сортов зарубежной селекции Стенлей и Президент, что способствует более полной реализации потенциальных возможностей растений.

Исследования проведены в рамках проекта Государственной Программы 20.80009.5107.18 «Целенаправленное формирование иммунной системы и качества плодов поздних сортов сливы, предназначенных для длительного хранения», финансируемой Национальным Агентством по Исследованиям и Развитию.

\section{Литература}

1. ШЕВЕЛУХА, В.Г. Современные проблемы гормональной регуляции живых систем и организмов/Регуляция роста и развития растений. Тез. докл. $1 \mathrm{~V}$ межд. конфер. М,1997, с.3-4.

2. TITOVA, N., ŞIŞCANU, Gh. Microelements as photosynthesis regulation in peach trees.//Abstr. XIth Int. Photosynthesis Congress. Budapest, 1998, p.3777-3780.

3. BUJOREANU, N., RALEA, T., MARINESCU, M., HAREA, I. Influența microelementelor asupra rezistenței mărului la calamitățile naturale //Mater.conf.naț. cu participare intern. «Probleme actuale ale geneticei, fiziologiei și ameliorării plantelor», Chișinău, 2008, p.279-285.

4. ȘIȘCANU, Gh. Fotosinteza și funcționalitatea sistemului donator-acceptor la plantele pomicole. Chișinău, 2018 (Tipografia AȘM). $316 \mathrm{p}$.

5. НИЧИПОРОВИЧ, А.А. Физиология фотосинтеза и продуктивность растений // Физиология фотосинтеза. М.: Наука,1982, с.7-33.

6. ШЛЫК, А.А. Определение хлорофиллов и каротиноидов в экстрактах зеленых листьев // Биохимические методы в физиологии растений. М.: Колос, 1971, с.154-170.

7. ЕРМАКОВ, А.И. и др. Методы биохимического исследования растений. М.:Агропромиздат, 1987. 430 с.

8. CHANCE, B., MACHELY, A. Assay of catalase and peroxidase. // Methods Enzymol., 1995, 2, p. 764-775.

9. МОКРОНОСОВ, А.Т. Донорно-акцепторные отношения в онтогенезе растения //Физиология фотосинтеза. М.: Наука,1982, с.235-258.

10. ХРАМЦОВА, Е.В., КИСЕЛЕВА, И.С., МАЛКОВА, Н.А. Взаимосвязь продукционных параметров с ростовыми и мезоструктурными характеристиками фотосинтетического аппарата рода Triticum L. //Современные проблемы сельского хозяйства. Калиинград, 2002, с.163-171.

11. ГЕНКЕЛЬ, П. А. Жаро - и засухоустойчивость растений. М.: Наука,1982. 227 с. 